\title{
UPAYA PERLINDUNGAN HUKUM INDIKASI GEOGRAFIS TERHADAP SALAK SIDIMPUAN SEBAGAI KEKAYAAN ALAM TAPANULI SELATAN
}

\author{
Dara Quthni Effida*, Etty Susilowati**, Kholis Roisah*** \\ Program Studi Magister Ilmu Hukum \\ Fakultas Hukum Universitas Diponegoro \\ r_kholis@yahoo.com
}

\begin{abstract}
ABSTRAK
Salak Sidimpuan yang berasal Tapanuli Selatan memiliki potensi untuk mendapatkan perlindungan hukum sebagai indikasi geografis. Penelitian ini menganalisis perlunya Salak Sidimpuan mendapatkan perlindungan hukum sebagai Indikasi Geografis Tapanuli Selatan dan upaya Pemerintah Daerah dalam rangka memberikan perlindungan terhadap Salak Sidimpuan sebagai kekayaan alam Tapanuli Selatan. Metode pendekatan penelitian yuridis empiris. Kabupaten Tapanuli Selatan menjadi lokasi penelitian dalam penelitian ini. Metode pengumpulan data melalui studi penelitian kepustakaan serta studi lapangan. Metode analisis dimulai dari pengumpulan data, reduksi data, penyajian data dan penarikan kesimpulan. Urgensi Salak Sidimpuan mendapatkan perlindungan hukum sebagai Indikasi Geografis Tapanuli Selatan karena secara ekonomis, salak sidimpuan memiliki pengaruh yang besar karena sebagian besar masyarakat Tapanuli Selatan perekonomiannya ditopang oleh buah Salak Sidimpuan. Secara Yuridis, Salak Sidimpuan yang memiliki karakteristik berbeda dengan salak daerah lain, memiliki reputasi yang baik, dan masih terjaga Eksistensinya sampai saat ini memerlukan perlindungan hukum sebagai Indikasi Geografis dan dapat dimiliki komunal bagi masyarakat Tapanuli Selatan. Upaya Pemerintah Daerah dalam memberikan perlindungan hukum terhadap Salak Sidimpuan hanya diberikan Pemerintah Daerah melalui Dinas Koperasi, Perindustrian dan Perdagangan Kabupaten Tapanuli Selatan. Pemerintah Daerah memberikan bimbingan, advokasi dan pembinaan terhadap Koperasi yang didirikan petani Salak Sidimpuan.
\end{abstract}

Kata Kunci: Indikasi Geografis; Perlindungan Hukum; Salak Sidimpuan.

\footnotetext{
* Mahasiswa Program Studi Magister IImu Hukum UNDIP

${ }^{* *}$ Penulis Kedua

${ }^{* * *}$ Penulis Ketiga, Penulis Koresponden
} 


\section{A. PENDAHULUAN}

\section{Latar Belakang}

Era globalisasi dan perdagangan bebas menuntut Indonesia agar dapat memproteksi diri namun tetap menghargai negara lain agar hubungan internasional tetap terjaga. Salah satu langkah Indonesia menghadapi globalisasi adalah dengan perlindungan terhadap Hak kekayaan Intelektual (HKI).

HKI terdiri dari jenis-jenis perlindungan yang berbeda, bergantung pada subyek (bentuk kekayaan intelektual) yang dilindungi. Hak Kekayaan Intelektual terdiri dari dua bidang, yakni: pertama, Hak Cipta (copyright), serta Neighbouring Right, terdiri dari IImu Pengetahuan, Seni dan Sastra. Kedua, Hak Milik Industri (Industrial Property Right), terdiri dari Paten (patent), Merek (trademark), Desain Industri (Industrial design), Desain Tata Letak Sirkuit Terpadu (layout design of integrated circuit), dan rahasia dagang (trade secret).

Indikasi Geografis merupakan bagian HKI yang di Indonesia pengaturannya melalui Undangundang Nomor 15 tentang Merek, dalam Pasal 56 menyebutkan: "Indikasi Geografis dilindungi sebagai suatu tanda yang menunjukkan daerah asal suatu barang, yang karena faktor lingkungan geografis termasuk faktor alam, faktor manusia, atau kombinasi dari kedua faktor tersebut, memberikan ciri dan kualitas tertentu pada barang yang dihasilkan."

Tanda dalam definisi indikasi geografis yang dimaksud merupakan nama tempat atau daerah maupun tanda tertentu lainnya yang menunjukkan asal tempat dihasilkannya barang yang dilindungi oleh indikasi geografis, Indikasi Geografis dapat dimohonkan terhadap barang-barang berupa hasil pertanian, produk olahan, hasil kerajinan tangan, atau barang lainnya.

Banyaknya produk daerah yang ada di Indonesia yang telah dikenal dan mendapatkan tempat di pasar internasional sehingga memiliki nilai ekonomi yang tinggi, perlu diikuti dengan perlindungan hukum untuk bisa melindungi komoditas tersebut dari praktek persaingan curang dalam perdagangan. ${ }^{1}$

Contoh kasus produk Indikasi Geografis Indonesia yang diklaim pihak asing sebagai merek dagang mereka adalah kopi arabika Gayo. Kopi Gayo dibuat dari salah satu varietas biji kopi Arabika yang terbaik di dunia yang tumbuh hanya di pusat dataran tinggi Aceh, dan diproduksi di daerah Aceh Tengah dan Bener Meriah, yang dikenal sebagai perkebunan biji kopi terbesar kedua di negeri ini. Kopi dinamai Gayo setelah

1 Saky Septiono, Perlindungan Indikasi Geografis dan Potensi Indikasi Geografis Indonesia, Subdit Indikasi Geografis Ditjen HKI: Kementerian Hukum dan HAM. RI, 2009, Halaman 1. 
masyarakat Gayo memproses bijinya. ${ }^{2}$ Perusahaan

Belanda yang berbasis di Amsterdam, Holland Coffee B.V. secara resmi mendaftarkan dan mengklaim kopi Gayo sebagai merek dagang perusahaan mereka. ${ }^{3}$

Kasus yang serupa dialami oleh masyarakat Toraja, meskipun kopi ditanam di Toraja, Sulawesi Selatan namun kopi toraja telah didaftarkan oleh perusahaan Jepang, Key Coffee Co. Key Coffee Co sebuah perusahaan jepang yang telah mendaftarkan merek kopi "Toraja" di Jepang pada tahun 1976. sebagai merek dagang mereka. ${ }^{4}$

Akibatnya produk asli Indonesia seperti Kopi Gayo dan Kopi Toraja tidak bisa langsung dipasarkan di pasar internasional kecuali melalui Holland Coffee B.V. dan Key Coffee Co sebagai merek dagang mereka. Untuk menghindari terjadinya pelanggaran tersebut, Peraturan Pemerintah Nomor 51 Tahun 2007 mengatur mengenai pemakaian indikasi geografis oleh pihak yang tidak berhak dalam Pasal 27 ayat (1) jika saat indikasi geografis tersebut didaftar telah ada tanda yang sama dengan indikasi geografis terdaftar dipakai oleh pihak lain yang tidak berhak, maka pemakaian atas tanda tersebut harus dihentikan pemakaiannya setelah 2 (dua) tahun sejak tanda dimaksud terdaftar sebagai Indikasi Geografis. Ayat

2 http://www.acehtengahkab.go.id/rf1, diakses pada tanggal 11 November 2014.

3 http://www.bkpm.go.id/id/node/1559, diakses pada tanggal 11 November 2014.

4 http://www.haki.lipi.go.id/utama.cgi, diakses pada tanggal 14 November 2014.
(2) jika tanda tersebut telah didaftar sebagai merek sebelumnya, masih tetap dimungkinkan pemakaian atas tanda Indikasi Geografis tersebut dengan syarat pemakain merek tersebut menyatakan kebenaran mengenai tempat asal barang dan menjamin bahwa pemakaian merek yang dimaksud tidak akan menyesatkan Indikasi geografis terdaftar.

Kopi Arabika Gayo pada tanggal 28 April 2010 dan Kopi Arabika Toraja pada tanggal 9 Oktober 2013 telah terdaftar sebagai Indikasi Geografis di Direktorat Jenderal Hak Kekayaan Intelektual Kementerian Hukum dan Hak Asasi Manusia maka berdasarkan Pasal 27 Peraturan Pemerintah Nomor 51 Tahun 2007 tentang Indikasi Geografis, maka pihak lain yang telah memakai namun tidak berhak menggunakan indikasi geografis dapat menggunakan tanda yang dimaksud untuk jangka waktu 2 (dua) tahun sejak tanda dimaksud terdaftar sebagai indikasi geografis.

Berkaitan dengan kekayaan alam Indonesia, Salak Sidimpuan merupakan komoditas unggulan asal Tapanuli Selatan. Salak Sidimpuan memiliki potensi untuk mendapatkan perlindungan hukum melalui pendaftaran karena memiliki kekhasan yang berbeda dengan jenis salak lain. Maka perlu tinjauan lebih lanjut mengenai pentingnya upaya perlindungan hukum indikasi geografis terhadap salak sidimpuan sebagai kekayaan alam Tapanuli Selatan, dan tinjauan lebih lanjut mengenai upaya 
Jurnal Law Reform

Volume 11, Nomor 2, Tahun 2015

pemerintah daerah dalam melindungi salak sidimpuan sebagai komoditas unggulan yang berpotensi indikasi geografis.

\section{Metode Penelitian}

Penelitian ini merupakan penelitian kualitatif dengan metode pendekatan Yuridis Empiris. Kabupaten Tapanuli Selatan menjadi lokasi penelitian dalam penelitian ini. Metode pengumpulan data melalui studi penelitian kepustakaan serta studi lapangan dengan informan Dinas Pertanian, Tanaman Pangan dan Holtikultura Kabupaten Tapanuli Selatan, Petani Salak, Pengusaha Salak dan Pembeli. Metode analisis dimulai dari pengumpulan data, reduksi data, penyajian data dan penarikan kesimpulan.

\section{Kerangka Teori}

a. Teori Perlindungan Hukum

1) Integratif \& Koordinatif: Menurut Fitzgerald, hukum bertujuan mengintegrasikan \& mengkoordinasikan berbagai kepentingan dalam masyarakat. ${ }^{5}$

2) Prediktif \& Antisipatif: Lili rasjidi dan I.B Wysa Putra berpendapat bahwa hukum dapat difungsikan untuk mewujudkan perlindungan yang sifatnya tidak sekedar adaptif dan fleksibel, melainkan juga

Satijipto Raharjo, 2000, IImu Hukum, Bandung: PT. Citra Aditya Bakti, Halaman 53.
Program Studi Magister Ilmu Hukum Fakultas Hukum Universitas Diponegoro

prediktif dan antisipatif. ${ }^{6}$ Hukum bertujuan memprediksi hal-hal yang dapat terjadi kedepan, sehingga dapat hal tersebut dapat di antisipasi oleh hukum.

3) Preventif \& Represif: Perlindungan hukum yang preventif bertujuan untuk mencegah terjadinya sengketa, yang mengarahkan tindakan pemerintah berikap hati-hati dalam pengambilan keputusan berdasarkan diskresi dan perlindungan yang represif bertujuan untuk menyelesaikan terjadinya sengketa, termasuk penangananya di lembaga peradilan. ${ }^{7}$

b. Teori Hak Milik

1) Teori Domeinleer. Hak seseorang untuk memiliki benda secara pribadi disebut hak dominium dan hak penguasa untuk mengatur penggunaan barang-barang disebut dengan hak imperium.

2) Teori Hak Milik Pribadi. Teori ini disebut juga accupation theory. Teori ini menyatakan bahwa hak individu untuk memiliki dan mengalihkan benda miliknya adalah hak alamiah/kodrati dari individu tersebut. Inti ajaran ini pertama kali

6 Lili Rasjidi dan I.B Wysa Putra, 1993, Hukum Sebagai Suatu Sistem, Bandung: Remaja Rusdakarya, Halaman 118.

7 Maria Alfons, 2010, Ringkasan Disertasi Doktor:Implementasi Perlindungan Indikasi Geografis Atas Produk-produk Masyarakat Lokal Dalam Perspektif Hak Kekayaan Intelektual, Malang: Universitas Brawijaya, Halaman 18. 
dikenalkan oleh John Locke dengan labour theory yang mendasarkan pada hukum alam (natural law).

3) Teori Kepemilikan Sosial. Teori kepemilikan social merupakan counter hegemoni atas teori kapitalis yang mendasarkan kepada kepemilikan bersama. Filosofi ini dibangun oleh Karl Marx yang mengutamakan kepentingan sosial sebagai suatu hal yang paling utama. $^{8}$

\section{B. HASIL PENELITIAN DAN PEMBAHASAN}

\section{Urgensi Perlindungan Hukum Salak} Sidimpuan sebagai Indikasi Geografis

\section{Tapanuli Selatan}

\section{a. Eksistensi Salak Sidimpuan}

Salak Sidimpuan telah dibudidayakan sejak 1930 oleh nenek moyang masyarakat Tapanuli Selatan. Salak merupakan salah satu komoditas unggulan kabupaten Tapanuli Selatan, jika dilihat dari angka produksinya, buah salak adalah buah yang produksinya paling banyak dibandingkan dengan buah-buah yang lain. Produksi buah salak pada tahun 2012 meningkat sebanyak 55,55 persen dari tahun sebelumnya. ${ }^{9}$

Jumlah produksi Salak Sidimpuan paling tinggi terdapat di 3 (tiga) kecamatan yakni: Angkola

\footnotetext{
8 Ridwan, Op.Cit, Halaman 8.

9 BPS Tapanuli Selatan, Tapanuli Selatan Dalam Angka 2013, Halaman 149.
}

Barat, Marancar dan Angkola Timur. Luas pertanaman salak $13.928 \mathrm{Ha}$ dengan produksi 236.793 ton pertahun. Areal pengembangan salak masih tersedia $15.000 \mathrm{Ha}$ demikian pula pertumbuhan luas tanam dan produksi masih positif yang berarti bahwa potensi dan kecenderungannya terus meningkat.

Area penanaman salak yang sangat luas menunjukkan bahwa walaupun Salak Sidimpuan telah dibudayakan ratusan tahun yang lalu namun eksistensi ${ }^{10}$ Salak Sidimpuan tetap dijaga sampai saat ini.

\section{b. Reputasi Salak Sidimpuan Sebagai Produk} Indikasi Asal Tapanuli Selatan.

Istilah reputasi dalam penjelasan Pasal 56 Ayat (1) Undang-undang Nomor 15 Tahun 2001 tentang Merek ini akan membawa pengaruh terhadap penentuan adanya "karakteristik" tertentu dari barang/produk yang akan memperoleh perlindungan indikasi geografis. Adanya reputasi selalu diidentikan dengan keberadaan suatu barang/produk tertentu yang telah memiliki suatu prestasi tertentu/luar biasa, atau "goodwill" in the business, sehingga membutuhkan proses perjalanan waktu yang relatif lama untuk suatu

\footnotetext{
10 Eksistensi menurut Kamus Besar Bahasa Indonesia adalah keberadaan, kehadiran yang mengandung unsur bertahan.
} 
produk supaya dikenal secara luas dikalangan masyarakat/konsumen. ${ }^{11}$

Salak Sidimpuan sudah dikenal dibanyak pasar di Indonesia, terutama di bagian barat Indonesia, agar reputasi baik dari Salak Sidimpuan tetap terjaga, perlu adanya perlindungan hukum berupa Indikasi Geografis. Reputasi baik juga ditunjukan dari kelompok tani dan koperasi yang memproduksi olahan buah salak, misalnya Koperasi Agro Rimba Nusantara (AGRINA) dalam beberapa pameran baik ditingkat Lokal maupun Nasional mendapatkan penghargaan diantaraya juara harapan di pameran produk UMKM Kementerian Perindustrian dan juara I produk kuliner Bank Sumut Award Tahun 2009, dan U.D Salacca yang mendapatkan penghargaan dari Kementerian Pertanian sebagai juara I nasional bidang inovasi produk unggulan berdaya saing pada Oktober 2014.12

Reputasi Salak Sidimpuan secara lebih nyata ditunjukkan dari produk olahan Salak Sidimpuan Kabupaten Tapanuli Selatan ini dengan didaftarkannya 5 (lima) produk olahan salak sebagai merek yang telah mendapat sertifikat Merek pada Oktober 2010 oleh Kementerian Hukum dan Hak Asasi Manusia, adapun merek olahan salak yang telah terdaftar antara lain:

11 Djulaeka, Konsep Perlindungan Hak Kekayaan Intelektual Perspektif Kajian Filosofis HaKI Kolektif-Komunal, Setara Press, Malang: 2014, Halaman 134.

12 http://www.sumutprov.go.id/berita-lainnya/557-gubsubuka-pekan-pasar-petani-sumut, diakses pada tanggal 29 Maret 2015.
NAJAGO, NAGOGO, NATABO, NAMORA, NAROBI. ${ }^{13}$

Indikasi geografis secara hukum memaksa produsen untuk mempertahankan mutu dan kualitas produk sesuai dengan buku persyaratan, sehingga dari sudut konsumen, tentu memberikan kepuasaan tersendiri terhadap produk yang memiliki reputasi dan kualitas yang terjamin memenuhi standar walaupun harga jual lebih mahal tetapi konsumen bisa menikmati produk dengan mutu yang sama dari waktu kewaktu.

\section{c. Karakteristik Salak Sidimpuan}

Karakteristik merujuk pada ciri suatu barang/produk, yang merupakan 'sesuatu' yang mudah untuk dikenali. Dengan kata lain, karakteristik merujuk pada adanya persyaratan tertentu yang sifatnya lebih memberikan makna khusus yang harus melekat pada barang/produk berbasis indikasi geografis.

Karakteristik Salak Sidimpuan terdapat pada daging buahnya yang berwarna kuning tua dan bersemburat merah. Rasa buahnya manis bercampur asam bentuknya bulat telur, kulit buah salak ini berwarna hitam kecoklatan dan bersisik besar. ${ }^{14}$ Karakteristik Salak Sidimpuan dipengaruhi oleh dominasi faktor alam antara lain tekstur tanah yang baik untuk tanaman salak, curah hujan yang

13 Pemilik Merek, Pendiri Koperasi Agro Rimba Nusantara (AGRINA), Pendiri UD Salacca adalah Gulma.

14 Redaksi Agromedia, Budidaya Salak Kiat Mengatasi Permasalahan Praktis, Jakarta: Agromedia Pustaka, 2008 , Halaman 8 
cukup, ketinggian tanah dari permukaan laut dan faktor iklim yang sesuai dengan tanaman salak.

Daerah Tapanuli Selatan secara geografis berada di belahan Barat Indonesia dan sebelah Selatan Pulau Sumatera yang terletak pada $0^{\circ}-2^{\circ}$ Lintang Utara dan $98^{\circ}$ - $99^{\circ}$ Bujur Timur. Tapanuli Selatan terdiri dari dataran rendah yang bergelombang sekaligus daratan tinggi dengan ketinggian antara 0-1.985m diatas permukaan laut. Kabupaten Tapanuli Selatan memiliki topografi miring, akibat dari perubahan ketinggian wilayah daratan rendah ke daratan tinggi yang cukup tajam. Topografi miring tersebut pada umumnya cocok untuk tanaman salak karena topografi miring umumnya memiliki drainase ${ }^{15}$ yang baik karenakan zona pengakaran tanaman salak relatif dangkal dan akarnya tidak tahan terhadap genangan air dan kekeringan.

Keadaan tanah di Tapanuli Selatan menjadi penentu karakteristik Salak Sidimpuan, tekstur tanah yang baik untuk tanaman salak, ketinggian tanah dan tingkat kesuburan tanah yang menyebabkan salak sidimpuan hanya dapat tumbuh subur di daerah Tapanuli Selatan. Apabila ditanam di daerah lain kualitas yang dihasilkan tidak sama dengan yang di tanam di Tapanuli

15 Drainase adalah lengkungan atau saluran air di permukaan atau di bawah tanah, baik yang terbentuk secara alami maupun dibuat oleh manusia. Dalam bahasa Indonesia, drainase bisa merujuk pada parit di permukaan tanah atau gorong-gorong di bawah tanah. Drainase berperan penting untuk mengatur suplai air demi pencegahan banjir.
Selatan, karena faktor alam inilah maka Salak Sidimpuan yang berasal dari Tapanuli Selatan lebih unggul daripada daerah lain.

\section{d. Perbedaan Salak Sidimpuan Tapanuli Selatan dengan Salak Lainnya di Indonesia.}

Jumlah produksi salak di Indonesia sangat tinggi, mencapai 1.030.412.00. dengan 5 (lima) provinsi utama penghasil salak terbanyak, diantaranya: Sumatera utara, Jawa Barat, Jawa Tengah, DI Yogyakarta dan Jawa Timur.

Kultivar $^{16}$ salak di Indonesia yang dikenal berkisar antara 20 sampai 30 jenis salak. Banyaknya jenis salak di Indonesia menjadikan buah salak sebagai salah satu komoditas unggulan Indonesia. Beberapa jenis salak yang terkenal di Indonesia antara lain: Salak Sidimpuan dari Sumatera Utara, Salak condet dari Jakarta, Salak pondoh dari Yogyakarta dan Salak Bali dari Bali17

Perbedaan Salak Sidimpuan dengan jenis salak lain yang ada di Indonesia dapat dilihat perbedaannya berdasarkan ciri masing-masing jenis salak. ciri yang terbentuk dipengaruhi oleh faktor alam masing-masing daerah pertumbuhan

16 Dalam dunia pertanian, kultivar diartikan sebagai sekelompok tumbuhan yang telah dipilih/diseleksi untuk suatu atau beberapa ciri tertentu yang khas dan dapat dibedakan secara jelas dari kelompok lainnya, serta tetap mempertahankan ciri-ciri khas ini jika diperbanyak dengan cara tertentu, baik secara seksual maupun aseksual. Dalam pembicaraan sehari-hari awam kerap kali menyebut kultivar sebagai varietas atau ras (ras lokal, landrace), meskipun sebenarnya masing-masing memiliki pengertian yang berbeda. Kultivar merupakan produk dari pemuliaan tanaman.

17 Wikipedia, http://id.wikipedia.org/wiki/Salak, diakses tanggal 22 Maret 2015. 
salak dan/atau faktor manusia termasuk budaya dalam mengelola buah salak di masing-masing daerah.

Salak Sidimpuan merupakan jenis salak ini berasal dari daerah Tapanuli Selatan, Sumatra Utara. Salak ini dikenal punya rasa yang segar dengan campuran antara manis dan asam yang pas. Berbentuk bulat telur, sisik besar, daging buah Salak Sidimpuan berwarna kuning bersemburat merah.

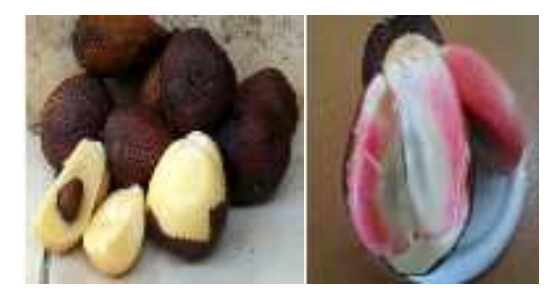

Gambar 4.1. Salak Sidimpuan

Salak Pondoh merupakan jenis Salak ini berasal dari Sleman, Yogyakarta. Salak ini terkenal di kalangan masyarakat karena rasanya yang manis, tidak sepet, dan daging buahnya tebal berwarna kekuningan kusam. Salak Pondoh dari Kabupaten Sleman merupakan varietas tanaman yang akhirnya memperoleh sertifikat indikasi geografis pada bulan Agustus tahun 2013. Dengan demikian indikasi geografis untuk varietas salak pondoh tersebut telah menjadi tanda pembeda dari varietas salak pondoh dari daerah lain, bahkan dengan varietas salak pada umumnya.

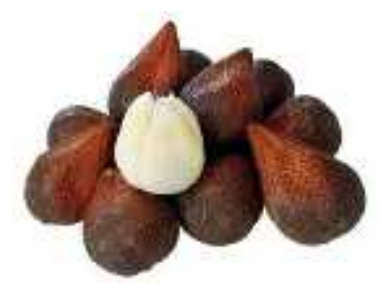

Gambar 4.2. Salak Pondoh

Salak Bali, seperti namanya salak ini berasal dari Bali. Salak bali lazimnya berukuran kecil, dengan daging buah tebal berwarna kuning, berbiji kecil, dan kulitnya bersisik kecil-kecil. Beberapa hasil pengembangan salak bali, yaitu salak gula pasir yang manis dan renyah, salak gondok merupakan jenis salak bali yang paling banyak jumlahnya, salak getih yang dagingnya kemerahan dan manis, salak cengkeh yang rasanya pedas, serta salak bingin yang biasanya dijadikan tanaman hias.

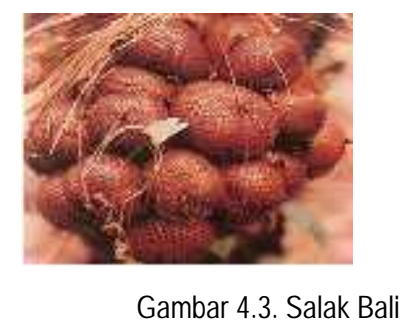

Salak Condet adalah jenis salak yang daerah asalnya Condet, Jakarta Timur. Identitas paling khas dari salak condet adalah aromanya yang wangi dan tajam, rasa salak ini manis tetapi agak sepat. Biasanya, salak condet berukuran besar, dengan biji yang besar dan sisik pada kulit yang juga besar-besar. ${ }^{18}$ Salak condet dipanen mulai

\footnotetext{
18 http://intisari-online.com/read/salak-salak-populer-diindonesia, diakses pada tanggal 21 Maret 2015.
} 
umur bunga 5 bulan karena pada umur tersebut salak condet memiliki kadar gula tertinggi.

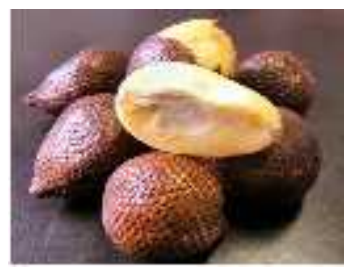

Gambar 4.4. Salak Condet

\section{Upaya Perlindungan Hukum Salak} Sidimpuan sebagai Kekayaan Alam Tapanuli Selatan Oleh Pemerintah Daerah

\section{a. Perlindungan Hukum oleh Pemerintah \\ Daerah}

Pemerintah Kabupaten Tapanuli Selatan berupaya untuk menjaga reputasi Salak Sidimpuan agar tetap menjadi produk unggulan daerahnya. Masyarakat yang pada umumnya petani salak berinisiatif dalam meningkatkan penjualan buah salak dengan melakukan pengolahan terhadap buah salak. Buah salak diolah menjadi makanan siap saji seperti dodol salak, kurma salak, sirup salak, agar-agar salak dan produk olahan lainnya. Dalam melakukan pengolahan buah salak tersebut, petani salak Tapanuli Selatan tergabung dalam Koperasi Agro Rimba Nusantara.

Pemerintah kabupaten Tapanuli Selatan melalui Dinas Koperasi, Perindustrian dan Perdagangan bertanggung jawab dalam memberikan bimbingan, advokasi, dan pembinaan terhadap Koperasi Agro Rimba Nusantara (AGRINA). Koperasi Agro Rimba Nusantara terletak di desa Parsalakan, Kecamatan Angkola Barat,
Kabupaten Tapanuli Selatan didirikan pada 2 Oktober 2007 yang bergerak dibidang pengolahan buah salak. Bentuk nyata dukungan dari Pemerintah Daerah Kabupaten Tapanuli Selatan melalui Dinas Koperasi, Perindustrian dan Perdagangan Kabupaten Tapanuli Selatan adalah pembangunan gedung sentra pengolahan buah salak di Desa Parsalakan Kecamatan Angkola Barat pada tahun 2007.

\section{Dukungan Pemerintah Kabupaten Tapanuli}

Selatan dalam upaya perlindungan terhadap Salak Sidimpuan sebagai kekayaan alam daerahnya, hanya sebatas perlindungan terhadap koperasi dibidang pengolahan buah salak. Sementara perlindungan hukum terhadap buah salak sendiri belum memadai, hal ini ditandai dengan belum adanya peraturan pemerintah daerah yang melindungi Salak Sidimpuan yang notabenenya merupakan komoditas unggulan dari daerah ini.

\section{b. Proses Perolehan Hak Indikasi Geografis}

Salak Sidimpuan akan memperoleh Hak indikasi geografis jika di daftarkan di Direktorat Jendral Hak Kekayaan Intelektuan Kementrian Hukum dan Hak Asasi Manusia Republik Indonesia. Prosedur pendaftaran produk-produk indikasi geografis diatur melalui Peraturan Pemerintah Nomor 51 Tahun 2007 Tentang Indikasi Geografis. ketentuan mengenai tatacara pendaftaran IndikasiGeografis dapat dikelompokkan menjadi:

1) Tahap Pertama: Mengajukan Permohonan. Adapun persyaratannya yaitu dengan 
melampirkan: Permohonan diajukan secara tertulis dalam bahasa Indonesia oleh Pemohon atau melalui Kuasanya dengan mengisi formulir dalam rangkap 3 (tiga) kepada Direktorat Jenderal, Surat kuasa khusus, apabila Permohonan diajukan melalui Kuasa, Bukti pembayaran biaya dan Buku Persyaratan.

2) Tahap Kedua: Pemeriksaan Administratif

3) Tahap Ketiga: Pemeriksaan Substansi

4) Tahap Keempat: Pengumuman

5) Tahap Ke Lima: Oposisi Pendaftaran.

6) Tahap Ke Enam: Pendaftaran

7) Tahap Ketujuh: Pengawasan terhadap Pemakaian Indikasi-Geografis

8) Tahap Kedelapan: Banding

\section{KESIMPULAN DAN SARAN}

\section{KESIMPULAN}

a. Urgensi Salak Sidimpuan mendapatkan perlindungan hukum sebagai Indikasi Geografis Tapanuli Selatan adalah sebagai berikut:

1) Segi Ekonomis, Salak Sidimpuan sangat berpengaruh dari segi ekonomi bagi masyarakat Tapanuli Selatan karena mata pencaharian masyarakat Tapanuli Selatan pada umumnya adalah petani. Sehingga pendapatan masyarakat Tapanuli Selatan sangat bergantung dari hasil Salak Sidimpuan yang dihasilkan.
2) Segi Yuridis, perlindungan hukum sebagai Indikasi Geografis perlu didapatkan oleh Salak Sidimpuan karena Salak Sidimpuan memenuhi syarat sebagai produk indikasi geografis dengan karakteristik khusus yang dipengaruhi oleh dominasi faktor alam Tapanuli Selatan.

b. Upaya Pemerintah Daerah dalam memberikan perlindungan hukum terhadap Salak Sidimpuan sebagai kekayaan alam Tapanuli Selatan belum memadai. Pemerintah Daerah melalui Dinas Koperasi, Perindustrian dan Perdagangan Kabupaten Tapanuli Selatan hanya memberikan bimbingan, advokasi dan pembinaan terhadap Koperasi Agro Rimba Nusantara (AGRINA).

\section{SARAN}

a. Pemerintah Daerah Kabupaten Tapanuli Selatan dalam hal ini Dinas Pertanian, Tanaman Pangan dan Holtikultura Kabupaten Tapanuli Selatan memahami Peraturan HKI terkait Indikasi Geografis, Manfaat Indikasi Geografis terhadap masyarakat, dan lebih memahami tentang Potensi Indikasi Geografis Daerahnya sehingga Pemerintah dapat memberikan sosialisasi mengenai Indikasi Geografis bagi masyarakat agar mereka paham bahwa Salak Sidimpuan yang mereka tanam, jaga reputasi dan karakteristiknya tersebut 
Jurnal Law Reform

Volume 11, Nomor 2, Tahun 2015

merupakan produk pertanian yang berpotensi mendapat perlindungan Indikasi Geografis, yang pada akhirnya dapat meningkatkan nilai jual dari Salak Sidimpuan.

b. Pendaftaran Salak Sidimpuan sebaiknya dilakukan oleh Pemerintah Daerah atau komunitas berbagai profesi yang peduli terhadap tanaman Salak Sidimpuan. Komunitas ini dibentuk dan berada di bawah pengawasan Pemerintah Daerah Tapanuli Selatan. Pendaftaran Salak Sidimpuan sebagai indikasi geografis dapat dilakukan apabila terjalin kerjasama antara Pemerintah Daerah dan masyarakat.

c.

\section{DAFTAR PUSTAKA}

Agromedia, 2008, Budidaya Salak Kiat Mengatasi Permasalahan Praktis, Jakarta: Agromedia Pustaka

Djulaeka, Konsep Perlindungan Hak Kekayaan I ntelektual Perspektif Kajian Filosofis HaKI Kolektif-Komunal, Setara Press, Malang: 2014

Lili Rasjidi dan I.B Wysa Putra, 1993, Hukum Sebagai Suatu Sistem, Bandung: Remaja Rusdakarya,

Maria Alfons, 2010, Ringkasan Disertasi Doktor:Implementasi Perlindungan Indikasi
Program Studi Magister Ilmu Hukum Fakultas Hukum Universitas Diponegoro

Geografis Atas Produk-produk Masyarakat Lokal Dalam Perspektif Hak Kekayaan Intelektual, Malang: Universitas Brawijaya

Satijipto Raharjo, 2000, Ilmu Hukum, Bandung: PT. Citra Aditya Bakti

Saky Septiono, 2009, Perlindungan Indikasi Geografis dan Potensi Indikasi Geografis Indonesia, Subdit Indikasi Geografis Ditjen HKI: Kementerian Hukum dan HAM. RI

BPS Tapanuli Selatan, Tapanuli Selatan Dalam Angka 2013

http://www.acehtengahkab.go.id/rf1

http://www.sumutprov.go.id/berita-lainnya/

557-gubsu-buka-pekan-pasar-petani-sumut http://www.bkpm.go.id/id/node/1559,

http://www.haki.lipi.go.id/utama.cgi,

http://id.wikipedia.org/wiki/Salak

http://intisari-online.com/read/salak-salak-populer-

di-indonesia 